\title{
Minat Beli Konsumen terhadap Produk Minuman Bubble Tea-Xi Bo Ba Jimbaran-Bali
}

\author{
Wayan Indah Silvia Permatasari', I Gusti Ayu Dewi Hendriyani², Putu Mira Astuti \\ Pranadewi ${ }^{3}$ \\ 1,2,3 Program Studi Manajemen Tata Hidangan, Politeknik Pariwisata Bali \\ Jl. Dharmawangsa Kampial, Nusa Dua Bali, Telp: (0361) 773537 \\ 1indahsilviapermatasari@gmail.com, 2dewi.hendriyani2@gmail.com, \\ ${ }^{3}$ mira.pranadewi2@gmail.com
}

\begin{tabular}{l|l|l} 
Received: Mei, 2020 & Accepted: Mei, 2020 & Published: June, 2020
\end{tabular}

\begin{abstract}
The purpose of this study was to determine consumers 'buying interest in Xi Bo Ba's beverage products, and consumers' responses to these products. This study used a qualitative descriptive analysis technique by collecting data using an online questionnaire on 60 respondents Xi Bo Ba Jimbaran Bali. Purchase interest variable consists of 3 dimensions, namely product quality, price, promotion with a total of 5 indicators. The results of the study of 60 respondents were the highest in women, mostly students aged 17-25 years. Respondents prefer shopping online rather than offline. The conclusion of all indicators of buying interest is in the very good category, with the highest indicator on product quality and the lowest on price. The advice for company management is to maintain what is good, improve what is still lacking, including new innovations in Xi Bo Ba's products in the future.
\end{abstract}

Keywords: beverages, Xi Bo Ba products, buying interest, price, promotion

\begin{abstract}
Abstrak
Tujuan penelitian ini adalah untuk mengetahui minat beli konsumen terhadap produk minuman Xi Bo Ba, dan tanggapan para konsumen dengan produk tersebut. Penelitian ini menggunakan teknik analisis deskriptif kualitatif dengan pengumpulan data menggunakan kuesioner secara online pada 60 orang responden Xi Bob Ba Jimbaran Bali. Variabel minat beli terdiri dari 3 dimensi yaitu kualitas produk, harga, promosi dengan total 5 indikator. Hasil penelitian dari 60 orang responden tertinggi pada wanita, lebih banyak oleh siswa dan mahasiswa dengan umur 17-25 tahun. Para responden lebih memilih berbelanja melalui online dibandingkan melalui offline. Kesimpulan dari keseluruhan indikator minat beli berada pada kategori sangat baik, dengan indikator tertinggi pada kualitas produk dan terendah pada harga. Saran bagi manajemen perusahaan adalah mempertahankan yang sudah baik, memperbaiki yang masih kurang termasuk inovasi yang baru dalam produk Xi Bo Ba ke depannya.
\end{abstract}

Kata kunci: minuman, produk Xi Bo Ba, minat beli, harga, promos 


\section{PENDAHULUAN}

Makanan dan minuman merupakan salah satu kebutuhan pokok terpenting bagi manusia, setiap harinya manusia memerlukan gizi dan cairan yang cukup demi kelangsungan hidupnya. Pada era globalisasi ini makanan dan minuman adalah suatu hal yang sangat menjanjikan dalam membuat suatu usaha. Banyaknya kalangan muda yang berlomba-lomba untuk membuka usaha seperti coffee shop, mini bar, restaurant dengan konsep yang seperti zaman sekarang yaitu instagramnable yang memiliki banyak keunikan didalamnya ditambah lagi dengan konsep makanan dan minuman yang berbeda dan menarik kalangan muda untuk datang dan mencobanya. Kini dengan banyaknya usaha-usaha yang berkembang sangat pesat, maka semakin banyak juga variasi makanan dan minuman yang ada didalamnya.

Salah satu minuman teh yang menjadi trend masa kini adalah minuman dengan toping boba. Minuman ini menjadi sangat terkenal dan banyak sekali yang mulai mencoba bisnis dengan menggunakan toping boba ini. Boba adalah bola tapioka yang sering menjadi isian dari minuman bubble tea. Boba berbahan dasar tepung tapioka, tepung tapioka ini tidak memiliki banyak rasa, maka Sebagian besar rasa manis dari boba tersebut berasal dari gula merah atau madu yang direndam sebelum disajikan. Bubble tea adalah minuman manis yang mengandung banyak gula, pada minuman ini sering ditambahkan perisa teh, susu, sirup serta toping lainnya, sehingga kadar gula, lemak dan kalori pada minuman ini cenderung tinggi. Apabila sudah diracik menjadi minuman bubble milk tea, 1 porsi standar (sekitar $475 \mathrm{ml}$ ) mengandung sekitar 38 gram gula dan 350-500 kalori. Kalori yang baik itu adalah 150 kalori per-hari untuk pria dewasa dan 100 kalori per-hari untuk wanita dewasa.

Minuman boba ini terkenal pertama kali di Taiwan. Menurut Fanny Low dari Biro Pariwisata Taiwan, boba mulai menjadi trend setelah diperkenalkan oleh Liu Han-Chieh, pemilik toko asal Taiwan bernama "Chun Shui Tang" di Taichung, Taiwan. Di Bali minuman dengan toping boba pertama kali dikenalkan oleh merk minuman bernama Chatime. Chatime merupakan minuman berbahan dasar teh, susu, maupun jus dengan cita rasa yang manis dengan berbagai macam varian rasa dan toping. Namun toping yang paling dikenal adalah boba. Dan di Indonesia termasuk di Bali umumnya sudah banyak sekali minumam-minuman yang menggunakan boba untuk menjadi bahan dasar dari topingnya. Salah satu minuman yang menjadi trend masa kini adalah Xi Bo Ba. Xi Bo Ba mulai muncul di Indonesia pada pertengahan September 2019. Xi Bo Ba masuk pertamakali di Jakarta Selatan pada 13 September 2019, dan masuk ke Bali pada 29 September 2019 di Merdeka Bali Jl. Merdeka No.9, Panjer, Denpasar. Dan kini Xi Bo Ba telah memiliki beberapa stand atau kedai di kota Denpasar dan di daerah Bali.

Saat ini, minat beli minuman yang menjadi tren dikalangan anak muda sudah menjadi gaya hidup dan bukan sekedar penghilang rasa haus. Ini terbukti banyaknya kedai minuman Xi Bo Ba di berbagai daerah di Bali seperti di daerah Jimbaran, Jalan Dewi Sri - Kuta, Renon, Batubulan, dan Sesetan-Denpasar. Di daerah Jimbaran, Badung Bali kedai Xi Bo Ba baru dibuka sejak bulan Pebuari 2020. Daerah Jimbaran.

Tabel 1: Data Penjualan minuman Xi Bo Ba Jimbaran periode bulan Pebuari - Juli 2020

[Sumber: Xi Bo Ba, Diolah (2020)]

\begin{tabular}{ccc}
\hline BULAN & PENJUALAN PER/CUP & PENDAPATAN \\
\hline Pebuari & $2.800 \mathrm{cup}$ & Rp. 71.500.000 \\
Maret & $1.400 \mathrm{cup}$ & Rp. 32.900 .000 \\
April & $2.376 \mathrm{cup}$ & Rp. 55.250 .000 \\
Mei & $2.740 \mathrm{cup}$ & Rp. 64.255.000 \\
Juni & $2.880 \mathrm{cup}$ & Rp. 67.600.000 \\
Juli & $2.938 \mathrm{cup}$ & Rp. 69.628.000 \\
\hline
\end{tabular}

Jurnal Gastronomi Indonesia Vol. 8. No. 1 
Berdasarkan Tabel 1 diatas dapat menunjukkan bahwa konsumen yang membeli produk minuman Xi Bo Ba ini mengalami kenaikan pada setiap bulannya. Namun pada bulan Maret memiliki penurunan karena adanya kasus covid-19 ini mengakibatkan penurunan sebanyak 50\% lalu pada bulan April, Mei, Juni dan Juli 2020 sudah terlihat kenaikan penjualan dan konsumen yang membeli produk minuman Xi Bo Ba Jimbaran ini.

Melihat ketertarikan konsumen untuk mencoba jenis dan rasa minuman yang berbeda, maka dianggap perlu untuk menganalisa minat beli konsumen terhadap minuman Boba di Xi Bo Ba Jimbaran yang masih tergolong baru dalam usaha sejenis serta keberlanjutan usaha ini ke depannya di tengah pandemi COVID 19. Pemilihan Xi Bo Ba sebagai tempat penelitian disebabkan karena Xi Bo Ba adalah kedai yang menjual minuman khusus untuk jenis boba dan olahan teh saja. Adapun varian rasa yang dapat dipilih yaitu Brown Sugar Boba Fresh Milk, Brown Sugar Boba Milk Tea, Salted Caramel Boba Fresh Milk Tea, Lychee Sakura Macchiato Popping Boba, Forest Berry Sakura Macchiato with Strawbrry Popping Boba, Yuzu Sakura Macchiato with Yoghurt Popping Boba, Black Tea Macchiato, Green Tea Macchiato, Hone Earl Grey Macchiato.

Sistem pelayanan yang digunakan oleh Xi Bo Ba ialah pesanan yang bisa dibawa pulang atau takeaway. Sebelum adanya pandemi Covid-19 ini sistem pelayanan di Xi Bo Ba ini memiliki tempat duduk outdoor untuk pembeli atau konsumen yang berbelanja namun ingin menikmatinya disana, namun karena adanya pandemi ini maka sistem pelayanan Xi Bo ba hanya bisa melalui takeaway atau pesan via online melalui grab atapun ojek online.

Pengertian minat beli konsumen Menurut Kotler dan Keller (dalam Suradi 2012), arti minat beli konsumen adalah sebuah perilaku konsumen dimana konsumen mempunyai keinginan dalam membeli atau memilih suatu produk, berdasarkan pengalaman dalam memilih, menggunakan dan mengkonsumsi atau bahkan menginginkan suatu produk. Berdasarkan uraian diatas dapat disimpulkan minat beli merupakan pernyataan mental dari konsumen yang merefleksikan rencana pembelian sejumlah produk dengan merek tertentu. Suatu produk dapat dikatakan telah dikonsumsi oleh konsumen apabila produk tersebut sudah diputuskan oleh konsumen untuk dibeli. Adapun 3 faktor yang mempengaruhi adanya minat beli konsumen menurut Martono dan Iriani (2014) yaitu kualitas produk, promosi, dan harga. Faktor ini nantinya akan dapat mengubah pendirian konsumen dalam melakukan pembelian. Minat konsumen tumbuh karena suatu motif berdasarkan atribut-atribut yang sesuai dengan kebutuhannya dalam menggunakan suatu produk.

Berdasarkan latar belakang masalah yang telah diuraikan diatas dapat di identifikasikan bahwa produk minuman Xi Bo Ba sangat digemari saat ini khususnya oleh milenial. Di tengah pandemic saat ini perlu kiranya di perhatikan hal-hal apa saja yang menjadi pertimbangan minat beli konsumen dalam mengkonsumsi minuman Xi Bo Ba khususnya outlet Jimbaran yang masih tergolong baru di tengah persaingan saat ini. Tujuan yang ingin dicapai dari penelitian ini adalah untuk mengetahui minat beli konsumen terhadap produk minuman bubble tea-Xi Bo Ba Jimbaran.

\section{KAJIAN PUSTAKA}

Kedai merupakan salah satu tempat yang menjual minuman dan makanan kecil seperti snack atau dessert, kedai juga termasuk salah satu restoran informal yang dimana orang-orang lebih fokus untuk menjual minuman dibandingkan dengan makanan. Dahulu orang-orang lebih mengenal kedai itu dengan tempat yang menjual kopi seperti coffee shop sehingga menurut Wiktionary (2010:22) bisa diartikan sebagai sebuah kafe kecil atau restoran kecil yang biasanya menjual kopi yang terkadang minuman non-alkohol, makanan sederhana atau snack, dengan fasilitas yang menunjang di tempat tersebut". Adapun pengertian lain dari coffee shop adalah menurut dalam kamus besar Bahasa 
Indonesia karya Poerwadarwita dikutip oleh (Anik, 2009) adalah sebuah tempat yang menjual kopi dan jenis minuman lain, serta makanan-makanan kecil dengan harga yang murah.

Kini semakin berkembangnya zaman dan semakin maju teknologi para pengusaha mulai mengembangkan kedai kopi sebagai suatu usaha yang menurutnya menjanjikan. Dengan banyaknya inovasi kedai kopi yang berkembang sangat pesat, namun kini Xi Bo Ba muncul dengan konsep kedai namun tidak menjual kopi melainkan menjual teh dengan campuran susu dan berisikan toping boba membuat para konsumen ingin mencobanya.

Minuman pada umumnya berbentuk cair yang di konsumsi oleh makhluk hidup sebagai sumber energi dan sebagai sumber kelangsungan hidup. Bagi manusia sendiri, minuman adalah hal yang sangat penting bagi tubuh manusia saat beraktifitas, manusia mengkonsumsi air putih yang bersih, jernih dan steril sebagai minuman untuk dikonsumsi dan juga baik untuk kesehatan. Jumlah air atau minuman yang dibutuhkan oleh tubuh manusia tersendiri juga cukup banyak yaitu beberapa liter air pada setiap harinya. Menurut Wiantara (2016:82) menyebutkan bahwa minuman adalah setiap cairan yang boleh diminum (drinkable liquid) kecuali obat-obatan.

Minuman adalah segala sesuatu yang diminum masuk ke dalam tubuh seseorang yang juga merupakan salah satu intake makanan yang berfungsi untuk membentuk atau mengganti jaringan tubuh, memberi tenaga, mengatur semua proses di dalam tubuh (Tarwotjo, 2008). Semakin berkembangnya zaman kini variasi minuman sudah memiliki banyak variasi dan jenisnya, minuman- minuman variasi ini sangat menarik bagi kaum muda atau anak milenial, karena minuman variasi itu sangat membooming di media sosial dan mudah dikenal banyak orang, maka semakin banyak yang memposting minumanminuman terbaru maka minuman tersebut akan menjadi minuman yang dicari-cari para kaum muda dan menjadikannya sebagai minuman masa kini atau minuman para anak muda. Adapun beberapa jenis minuman yang ada menurut Tarwotjo (2008), adalah: 1). Minuman sehari-hari adalah jenis minuman yang dikonsumsi setiap hari contohnya seperti: air putih, kopi dan teh, 2). Minuman hangat adalah jenis minuman yang cocok dikonsumsi saat musim dingin seperti musim hujan, minuman hangat ini mampu menghangatkan tubuh dan tenggorokan. Contoh minuman hangat adalah: wedang jahe, wedang ronde dan lain-lain, c). Minuman dingin adalah jenis minuman yang cocok dikonsumsi saat musim panas atau kemarau, jenis minuman ini sebagai penyejuk tubuh dan dahaga disaat siang hari. Contoh minuman dingin adalah: es buah, es sirup, jus buah, es krim dan minuman ringan (soft drink).

Teh merupakan sejenis minuman yang dihasilkan berasal dari pengolahan daun tanaman teh. Minuman teh dibuat dari pucuk daun teh muda, pengolahan daun teh sebelum menjadi minuman teh harus difermentasi, fermentasi daun teh lebih tepat disebut dengan proses oksidasi karena proses nya dibantu oksigen. Tanaman teh memiliki kandungan senyawa kimia, daun teh memiliki senyawa antioksidan yang disebut katekin, tanaman teh juga memiliki kandungan yang sama dengan kopi yaitu senyawa kafein, dan juga memiliki senyawa kimia lainnya yang begitu penting seperti asam amino serta senyawa folifenol.

Teh pertama kali dikenal 4000 tahun dan ditemukan oleh orang-orang cina, penemu teh pertama kali adalah Kaisar China bernama Shen Nong. Berasal dari kebiasaan kaisar yang meminum air matang untuk memastikan kebersihan nya pada tahun 2737 SM, pada saat air sedang dimasak secara tidak sengaja daun teh jatuh ke air tersebut, dan kaisar kemudian menyukai air tersebut dan itulah awal dari minuman teh. Teh mulai masuk ke Indonesia pada tahun 1684, dan dibawa oleh orang Jerman bernama Andreas Cleyer, bibitnya berasal dari Jepang. Percobaan penanaman teh dengan skala besar dimulai tahun 1827 oleh Jacobus Isidorus Loudewijk Levian Jacobson yang waktu itu Indonesia masih dijajah Belanda, penanaman dilakukan diwilayah Purwakarta dan Banyuwangi. 
Konsumen adalah seseorang yang membeli atau menggunakan produk, barang atau jasa yang dipasarkan. Konsumen bisa dibagi menjadi dua bagian yaitu konsumen personal dan konsumen organisasional. Konsumen personal atau bisa dibilang konsumen individual adalah konsumen yang membeli suatu produk untuk kebutuhan pribadi, keluarga maupun hewan peliharaannya. Sedangkan konsumen organisasional adalah konsumen yang membeli suatu produk yang akan dijual kembali nantinya yang bertujuan untuk menguntungkan pihak perusahaan. Menurut Dewi (2013:1), konsumen adalah seseorang yang menggunakan produk dan atau jasa yang dipasarkan. Sedangkan menurut Sri Handayani (2012: 2) konsumen (sebagai alih bahasa dari konsumen), secara harfiah berarti seseorang yang membeli barang atau menggunakan jasa atau seseorang atau sesuatu perusahaan yang membeli barang tertentu atau menggunakan jasa tertentu juga sesuatu atau seseorang yang menggunakan suatu persediakan atau sejumlah barang, ada pula yang memberikan arti lain yaitu konsumen adalah setiap orang yang menggunakan barang atau jasa dalam berbagai perundang-undangan negara.

Menurut Gunawan dalam Awaliyah (2017:14) perilaku konsumen adalah suatu studi bagaimana individu, kelompok, dan organisasi atau lembaga memilih, membeli, menggunakan, dan membuang barang, jasa, ide, atau pengalaman untuk memuaskan kebutuhan dan keinginan konsumen. Dari beberapa definisi diatas mengenai pengertian konsumen dapat disimpulkan bahwa konsumen merupakan seseorang yang membeli produk dengan tujuan untuk menggunakan produk tersebut sebagai barang yang akan dipakai, dikonsumsikan ataupun akan dijadikan persediaan. Kepuasan konsumen adalah dimana harapan seorang konsumen yang membeli suatu produk yang melebihi ekspetasi mereka yang dipenuhi atau dilebihi oleh sebuah produk. Kepuasan konsumen akan sangat menguntungkan bagi para pengusaha karena jika para konsumen merasa sangat puas terhadap produk yang ditawarkan, mereka akan datang lagi dan lagi untuk membeli bahkan mereka secara tidak langsung akan mempromosikan produk tersebut kepada teman-teman dan social media.

Berikut beberapa alasan tersendiri dari konsumen yang menjadikan produk atau merek tersebut sebagai kepercayaannya untuk membeli lagi dan lagi, yaitu dengan menggunakan 4P. Menurut McCarthy (dalam Akhmad Sefudin, 2014:20) 4P terdiri dari Product, Price, Promotion, Place. Kualitas produk dan jasa yang baik tentu saja akan memberikan kepuasan yang tinggi dari konsumen. Dan pentingnya melakukan atau meminta kritikan dan saran dari konsumen baik buruknya kritikan dan saran tersebut tampunglah dan jadikan sebagai bahan pertimbangan dan perbaikan. Harga adalah salah satu hal yang sensitif dalam sebuah bisnis. Umumnya konsumen akan menjadikan harga sebagai patokan untuk membandingkan anda dengan para pesaing. Promosi merupakan ujung tombak untuk memperkenalkan produk atau jasa kepada masyarakat. Kini kegiatan pemasaran atau promosi sangat mudah dilakukan dengan memanfaatkan media sosial seperti Facebook, Instagram, memasang iklan, kerja sama sponsorship, mengikuti bazar. Tempat atau lokasi merupakan salah satu faktor penentu bisnis. Pilihlah lokasi yang strategis dan benar, maksudnya pemilihan lokasi yang strategis merupakan lokasi yang ramai dilalui banyak orang. Sehingga calon konsumen ataupun konsumen tertarik serta mudah untuk menemukan lokasi atau tempat jualan. Kesimpulannya adalah konsumen akan tertarik untuk membeli suatu produk karena produk tersebut memang terpercaya, dengan harga yang mudah dijangkau oleh berbagai kalangan, lokasi yang mudah diakses dan mudah ditemui, serta selalu memberikan promosi atau memberikan inovasi terbaru.

Minat beli merupakan suatu keinginan dalam diri konsumen terhadap suatu produk sebagai dampak dari suatu proses pengamatan dan pembelajaran konsumen atau individu terhadap suatu produk dan memiliki keinginan untuk membeli dan memiliki produk tersebut. Kebutuhan dan keinginan konsumen akan barang dan jasa semakin berkembang dari masa ke masa dan mempengaruhi perilaku mereka terhadap pembelian suatu produk. 
Menurut Kotler dan Keller (dalam Suradi, 2012), arti minat beli konsumen adalah sebuah perilaku konsumen dimana konsumen mempunyai keinginan dalam membeli atau memilih suatu produk, berdasarkan pengalaman dalam memilih, menggunakan dan mengkonsumsi atau bahkan menginginkan suatu produk. Minat beli dibentuk dari sikap konsumen terhadap produk yang terdiri dari kepercayaan konsumen terhadap merek dan evaluasi merek, sehingga dari dua tahap tersebut muncullah minat untuk membeli (Setiadi, 2011:216).

Menurut Davidson $(2015 ; 140)$ minat beli konsumen dapat diartikan sebagai berikut minat beli mencerminkan hasrat dan keinginan konsumen untuk membeli suatu produk. Menurut Kinnear dan Taylor (2016:24) minat beli adalah komponen perilaku konsumen dalam mengonsumsi, kecenderungan responden untuk bertindak sebelum memutuskan pembelian produk. Berdasarkan dari beberapa definisi diatas dapat disimpulkan bahwa minat beli merupakan keinginan konsumen terhadap suatu produk berdasarkan pengalaman, kepercayaan terhadap suatu merek, hasrat atau keinginan untuk membeli dan mengonsumsi suatu produk.

Menurut hasil penelitian Martono dan Iriani (2014) juga menemukan bahwa kualitas produk, harga, dan promosi berpengaruh signifikan terhadap minat beli. Adapun 3 faktor yang mempengaruhi minat beli konsumen ini antara lain: 1). Kualitas Produk. Kualitas (quality) adalah totalitas fitur dan karakteristik produk atau jasa yang bergantung pada kemampuannya untuk memuaskan kebutuhan yang dinyatakan atau tersirat (Kotler dan Keller, 2012:143). Menurut Kotler dan Armstrong (dalam Martono, 2014) kualitas produk adalah kemampuan sebuah produk dalam memperagakan fungsinya, hal itu termasuk keseluruhan durabilitas, reliabilitas, ketepatan, kemudahan pengoperasian dan reparasi produk juga atribut produk lainnya, 2). Harga adalah kesepakatan nilai yang menjadi persyaratan bagi pertukaran dalam sebuah transakasi pembelian. Harga adalah sejumlah uang yang dibebankan atas suatu produk atau jasa, atau jumlah dari nilai yang ditukar konsumen atas manfaat-manfaat karena memiliki atau menggunakan produk atau jasa tersebut (Kotler dan Armstrong, 2010:314). Harga merupakan satu-satunya unsur bauran pemasaran yang memberikan pendapatan bagi organisasi. Secara sederhana harga dapat diartikan sebagai jumlah (satuan moneter) dan atau aspek lain (non moneter) yang mengandung utilitas atau kegunaan tertentu untuk mendapatkan suatu produk (Tjiptono, 2012:231), dan 3). Promosi. Kotler (2010:173) mengemukakan bahwa promosi penjualan adalah insentif jangka pendek untuk mendorong pembelian atau penjualan dari suatu produk atau jasa. Sedangkan menurut William J Stanton promosi merupakan periklanan, penjualan personal dan lain-lain cara penjualan tujuan promosi penjualan. Kotler (2010:174) menjelaskan bahwa promosi bertujuan untuk menarik konsumen agar mau mencoba produk baru, memancing konsumen agar meninggalkan produk pesaing, atau untuk membuat konsumen meninggalkan produk yang sudah matang, atau menahan atau member penghargaan pada konsumen yang loyal.

Jadi 3 indikator minat beli menurut penelitian Martono dan Iriani (2014) inilah yang akan digunakan untuk kuesioner yang nantinya akan disebarkan kepada konsumen Xi Bo Ba untuk mengetahui bagaimana minat beli penilaian mereka kepada produk minuman Xi Bo Ba. Menurut Dama (2016:505) menyatakan adanya beberapa faktor-faktor yang mempengaruhi minat beli konsumen diantaranya: 1). Perilaku Konsumen adalah tingkah laku dari konsumen, dimana mereka dapat mengilustrasikan pencarian untuk membeli, menggunakan, mengevaluasi dan memperbaiki suatu produk dan jasa mereka. Focus dari perilaku konsumen adalah bagaimana individu membuat keputusan untuk menggunakan sumberdaya mereka yang telah tersedia untuk mengkonsumsi suatu barang, 2). Minat Beli Konsumen. Minat beli merupakan bagian dari komponen perilaku dalam sikap mengkonsumsi. Menurut Kinnear dan Taylor (Sukmawati dan Durianto) minat membeli adalah bagian dari komponen perilaku konsumen dalam sikap mengkonsumsi, kecenderungan responden untuk bertindak sebelum keputusan membeli benar-benar 
dilaksanakan, 3). Promosi dapat didefinisikan sebagai suatu bentuk komunikasi pemasaran, komunikasi pemasaran adalah aktivutas pemasaran yang berusaha menyebarkan informasi, mempengaruhi/ membujuk dan/atau mengingatkan pasar sasaran atas perusahaan dan produknya agar bersedia menerima, membeli, dan loyal pada produk yang ditawarkan perusahaan yang bersangkutan.

Sedangkan menurut Simamora dalam (Susanto \& Rahmi, 2013: 62) mengungkapkan ada beberapa faktor yang mempengaruhi minat pembelian seorang konsumen terhadap suatu produk yaitu: 1). Mutu kualitas produk, merupakan nilai dan manfaat yang diberikan produk pada konsumen yang mengkonsumsi produk yang menimbulkan kenyamanan dan kepuasan dan rasa tertarik untuk membeli produk, 2). Harga, merupakan sejumlah pengorbanan ekonomi yang diberikan konsumen untuk membeli sebuah produk yang sangat tergantung pada anggaran yang dimiliki seorang konsumen untuk membeli produk, 3). Desain produk, merupakan corak yang melatarbelakangi produk yang pada akhirnya menimbulkan rasa tertarik untuk membeli produk, 4). Distribusi, merupakan penyaluran untuk dapat dengan mudah ditemui oleh konsumen.

Pengertian minat beli ulang atau bisa juga disebut membeli kembali menurut penelitian Nurhayati dan Wahyu (2012:53) adalah kenginan dan tindakan konsumen untuk membeli ulang suatu produk, karena adanya kepuasan yang diterima sesuai yang dinginkan dari suatu produk. Merk yang sudah melekat dalam hati pelanggan akan menyebabkan pelanggan melanjutkan pembelian atau pembelian ulang. Menurut Fornell dalam Hendarsono dan Sugiharto (2013) mengatakan bahwa konsumen yang merasa puas akan melakukan kunjungan ulang di masa mendatang dan juga memberitahukan kepada orang lain atas produk atau jasa yang dirasakan. Berdasarkan definisi diatas dapat diartikan bahwa minat beli ulang atau minat dalam pembelian kembali itu dikarenakan adanya kepuasan tersendiri yang dirasakan oleh konsumen dan kepuasan tersebut bisa saja membuat para konsumen secara tidak langsung untuk mempromosikan produk tersebut kepada orang lain dan membuat mereka untuk lagi dan lagi untuk datang dan membeli produk tersebut.

\section{METODE PENELITIAN}

Objek Penelitian ini adalah konsumen terhadap minat beli produk minuman Xi Boba. Lokasi penelitian yang akan diambil adalah Xi Boba Jimbaran. Teknik pengumpulan data menggunakan (1) Wawancara dan (2) Kuesioner (3) Dokumentasi.

Analisis data yang digunakan dalam penyusunan ini adalah teknik analisis deskriptif kualitatif yaitu dengan cara data yang diperoleh dari hasil angket, kemudian dideskriptifkan secara menyeluruh. Menurut Sugiono (2016) analisis data adalah mencari dan menyusun secara sistematis data yang diperoleh dari hasil wawancara, catatan lapangan, dan dokumentasi, dengan cara mengorganisasikan data ke dalam kategori, menjabarkan ke dalam unit unit, melakukan sintesa, dan membuat kesimpulan sehingga mudah di pahami oleh diri sendiri maupun orang lain. Pengolahan data dilakukan dengan cara data yang telah dikumpulkan, diolah, dan disajikan dalam bentuk tabel dalam hal ini produk minuman Xi Bo Ba Jimbaran dengan teori yang sudah ada, sehingga mendapatkan kesimpulan secara logis. Adapun langkah kerja yang digunakan untuk menganalisa data tersebut adalah sebagai berikut: (1) Menyebarkan kuesioner kepada responden. Jumlah sampel yang dipakai dihitung dari jumlah indikator dikalikan 10 (Hair, 2010) sehingga minimal jumlah responden adalah 50 orang. Pembuatan kuesioner tersebut menggunakan metode skala likert. Mengekspresikan tingkat pendapatan mereka mengenai pelayanan yang diterima dengan rincian sebagai berikut: (a). Penilaian dengan skor 5 , berarti sangat baik, (b). Penilaian dengan skor 4, berarti baik, (c). Penilaian dengan skor 3, berarti cukup, (d). Penilaian dengan skor 2, berarti kurang, (e). Penilaian dengan skor 1, berarti sangat kurang. (2) Mengumpulkan kuesioner. (3) Mentabulasi hasil kuesioner. (4) Mencari nilai 
mean. Untuk menganalisa frekuensi munculnya segala kejadian yang didasarkan pada skala penelitian rumus yang digunakan adalah :

$$
\text { Mean }=\frac{\sum(\mathrm{F} 1 \times 1+\mathrm{F} 2 \times 2+\mathrm{F} 3 \times 3+\mathrm{F} 4 \times 4+\mathrm{F} 5 \times 5)}{\mathrm{F} 1+\mathrm{F} 2+\mathrm{F} 3+\mathrm{F} 4+\mathrm{F} 5}
$$

Keterangan : F1×1 adalah jumlah hasil dari nilai tengah di kali dengan frekuensi, F1 adalah jumlah frekuensi. Memasukan nilai mean kedalam interval, untuk mendapat data kuantitatif melalui kuesioner tersebut, nilai pernyataan dihitung dengan mengalikan seluruh frekuensi data dengan bobot, hasil dibagi dengan jumlah responden yang telah mengisi kuesioner dengan lengkap. Interval kelas sebagai berikut: (1). Sangat kurang: interval 1,00 s/d < 1,80; (2). Kurang: interval 1,80 s/d < 2,60; (3). Cukup: interval 2,60 s/d $<3,40$; (4). Baik: interval 3,40 s/d < 4,20; (5). Sangat Baik: 4,20 s/d $\leq 5,00$

Indikator yang akan digunakan dalam penelitian ini adalah indikator minat beli konsumen. Hasil penelitian Martono dan Iriani (2014) juga menemukan bahwa kualitas produk, harga, dan promosi berpengaruh signifikan terhadap minat beli. Adapun 3 faktor yang mempengaruhi minat beli konsumen ini antara lain: (1) Kualitas Produk adalah totalitas fitur dan karakteristik produk atau jasa yang bergantung pada kemampuannya untuk memuaskan kebutuhan yang dinyatakan atau tersirat, (2) Harga adalah kesepakatan nilai yang menjadi persyaratan bagi pertukaran dalam sebuah transakasi pembelian, (3) Promosi bertujuan untuk menarik konsumen agar mau mencoba produk baru, memancing konsumen agar meninggalkan produk pesaing, atau untuk membuat konsumen meninggalkan produk yang sudah matang, atau menahan atau memberi penghargaan pada konsumen yang loyal. Minat beli merupakan suatu proses belajar dan proses pemikiran yang membentuk suatu presepsi. Dalam penelitian ini yang hendak diteliti adalah minat beli konsumen terhadap minuman Xi Bo Ba Jimbaran. Dan minat beli ini dipengaruhi dengan beberapa faktor kualitas produk, harga dan promosi.

\section{PEMBAHASAN}

Munculnya trend minuman kekinian Bubble Tea atau yang lebih dikenal dengan Boba, menjadi peluang usaha yang menjanjikan untuk dijalankan. Hal inilah yang kemudian memunculkan ide bagi Michelle Sulistyo dan kelima rekannya, sebagai pemilik Kulo Group untuk meluncurkan brand minuman segar Boba khas Taiwan dengan menghadirkan Xi Bo Ba pada September 2019. Mungkin selama ini banyak masyarakat yang menyangka bahwa Xi Bo Ba sebagai brand waralaba asing karena nama dan cita rasa khas ala Taiwan yang begitu kental. Michelle mengatakan bahwa nama Xi Bo Ba terinspirasi dari kata Xi Yue yang berarti Joy atau kebahagiaan. Xi Bo Ba ingin memberikan kebahagiaan kepada setiap orang yang meminumnya melalui rasa yang khas dari Taiwan. Kami ingin konsumen senang setelah mengonsumsi minuman ini karena rasanya dan harganya yang pas di kantong," tuturnya. Xi Bo Ba sendiri menawarkan beragam jenis varian bubble tea dengan harga yang sangat terjangkau mulai dari Rp17.000 tetapi tetap memiliki rasa dan kualitas yang terbaik. Beberapa produk andalannya antara lain Fresh Milk hingga milk tea dengan signature menu yaitu Fresh Milk Boba yang banyak di gemari oleh masyarakat Indonesia karena kenikmatan tekstur boba yang lembut dan juicy.

Dengan rasanya yang nikmat dan harga yang terjangkau, Xi Bo Ba ternyata berhasil mencuri hati para penikmat boba di Indonesia. Saat ini Xi Bo Ba telah memiliki lebih dari 200 gerai di seluruh Indonesia, bahkan tercatat sebagai merek minuman boba dengan ekspansi outlet tercepat dan terbesar di Indonesia. Xi Bo Ba ini masuk ke Bali pada akhir bulan November tahun. Xi Bo Ba Jimbaran merupakan cabang ke delapan dibuka pada tanggal 28 Pebuari - 1 Maret 2020. Yang berlokasikan di Jl. Uluwatu II No. 108 Badung, Bali. 
Kedai Xi Bo Ba ini melayani sistem take away atau bawa pulang, kedai Xi Bo Ba sendiri menyediakan tempat duduk yang bisa digunakan oleh para konsumen atau pembeli jika mereka ingin duduk-duduk santai sambil menikmati minuman Xi Bo Ba ini, mereka menyediakan 4 meja dengan sepasang kursi atau 8 sitting. Karena pada saat pandemic ini kedai Xi Bo Ba memilih untuk menggunakan sistem pelayanan take away, dan kebanyakan yang datang dan membeli minuman adalah para ojek online. Xi Bo Ba sendiri menjual minuman teh dengan berbagai variasi seperti Brown Sugar Boba Fresh Milk, Brown Sugar Boba Milk Tea, Salted Caramel Boba Fresh Milk Tea, Lychee Sakura Macchiato Popping Boba, Forest Berry Sakura Macchiato with Strawbrry Popping Boba, Yuzu Sakura Macchiato with Yoghurt Popping Boba, Black Tea Macchiato, Green Tea Macchiato, Honey Earl Grey Macchiato.

Kedai Xi Bo Ba buka mulai pukul 10.00 wita sampai dengan pukul 22.00 WITA. Hampir setiap hari kedai Xi Bo Ba penuh dikunjungi oleh ojek online, karena sebagian besar para konsumen memilih untuk diam dirumah dan memesan via online menggunakan ojek online atau go food. Dengan konsep kedai yang outdoor membuat para pembeli mudah untuk menemukan kedai Xi Bo Ba ini. Walaupun menggunakan konsep outdoor namun kedai $\mathrm{Xi}$ Bo $\mathrm{Ba}$ ini tetap nyaman untuk dikunjungi meskipun terletak dipinggir jalan.

Produk minuman Xi Bo Ba merupakan suatu minuman teh yang mulai terkenal karena banyak masyarakat yang mengetahui tentang produk minuman Xi Bo Ba ini. Minat beli pada produk-produk minuman ini cukup tinggi, karena tingginya minat beli, promosi dan infomasi yang diberikan oleh Xi Bo Ba ini. Minat beli juga merupakan faktor utama dalam pemasaran suatu produk dan juga mempengaruhi keberhasilan suatu produk yang dijual. Hal ini perlu diperhatikan dalam mempromosikan produk yang dijual seperti produk minuman Xi Bo Ba, sehingga konsumen yang menaruh minat beli kepada minuman Xi Bo Ba ini akan cenderung menyukai dan memberikan rekomendasi produk tersebut ke teman atau keluarga terdekat. Sebaliknya jika minat beli tidak diperhatikan maka produk yang dijual tidak akan berkembang dan akan mengalami daya jual yang terus menurun dikarenakan banyaknya produk baru yang unggul dan memiliki daya minat beli yang lebih tinggi.

Penelitian ini dilaksanakan selama periode waktu 1 bulan yaitu bulan Juli 2020 dengan menyebarkan angket kepada responden dan wawancara kepada pemilik maupun pelanggan. Jumlah target responden untuk mengisi kuesioner penelitian ini adalah minimal 50 orang responden. Untuk mengetahui minat beli konsumen terhadap produk minuman Xi Bo Ba di daerah Jimbaran, untuk melakukan penelitian akan diberikan google form kepada responden yang berisikan beberapa pertanyaan mengenai Xi Bo Ba Jimbaran. Target responden adalah pria/ wanita yang berumur 17-25 tahun, 25-35 tahun dan <35 tahun yang dimana profesi diantara siswa/mahasiswa, karyawan dan wirausaha. Beberapa pertanyaan wawancara kepada pelanggan adalah produk apa yang disukai, cara membeli produk apakah online atau offline, dan alasan membeli produk minuman Xi Bo Ba Jimbaran.

Harga yang ditawarkan oleh Xi Bo Ba pun bervariasi mulai dari harga Rp.17.000 hingga Rp.26.000 dan rasa yang ditawarkan bervariasi mulai dari The Bobas yang artinya minuman dengan campuran fresh milk dengan toping boba, Sakura Macchiato Series yang dimana varian rasa ini terbuat dari green tea atau teh hijau yang dipadukan dengan beberapa rasa buah seperti lychee, berry dan yuzu diberikan toping yaitu popping boba, popping boba ini memiliki rasa yang terbilang unik karena jika diminum akan meledak dimulut dan didalamnya berisikan rasa buah-buahan. Adapula rasa Tea Macchiato Series yaitu rasa yang dibuat dari teh seperti teh hitam, teh hijau dan teh earl grey.

Berdasarkan paparan data diatas serta berpedoman pada referensi sumber yang didapat serta dari teori minat beli Martono dan Iriani (2014) menyebutkan bahwa kualitas produk, harga, dan promosi berpengaruh signifikan terhadap minat beli. Penyusunan 
angket enelitian menggunakan Google form yang berpedoman pada penelitian sebelumnya yang didalamnya memuat variabel dari beberapa faktor tersebut dengan memakai beberapa indikator yang berhubungan dengan minat beli konsumen. Adapun beberapa langkah kerja yang dilakukan untuk menganalisa bagaimana minat beli konsumen terhadap produk minuman Xi Bo Ba sebagai berikut: (1) Menyebarkan kuesioner online kepada konsumen yang pernah membeli produk minuman Xi Bo Ba Jimbaran, untuk memberikan penilaian mengenai beberapa hal yang berhubungan terhadap minat beli konsumen terhadap produk minuman Xi Bo Ba. Hasil penyebaran kuesioner selama periode penelitian di dapatkan hasil 60 orang responden. Kemudian setiap hasil kuesioner diberikan bobot / skor penilaiannya. (2) Mentabulasi hasil kuesioner dengan mencari nilai rata-rata (mean). Memecahkan masalah dengan menggunakan mean yang merupakan jumlah seluruh data dibagi dengan banyaknya data serta memaparkan ke dalam bahasa yang mudah dimengerti (Sugiyono, 2013). (3) Selanjutnya perhitungan akan dilakukan dengan mengklasifikasikan skor menurut interval kelasnya masing-masing.

Berikut adalah Tabel 2 hasil penilaian kepada produk minuman Xi Bo Ba Jimbaran terhadap indikator minat beli konsumen dari hasil olah data:

Tabel 2: Tabel Hasil Penilaian Kepada Konsumen Xi Bo Ba Jimbaran Terhadap indikator Minat Beli Konsumen periode Juli 2020

[Sumber: Hasil Tabulasi Kuesioner (data diolah, 2020)]

\begin{tabular}{|c|c|c|c|c|c|}
\hline No & Variabel & Indikator & $\begin{array}{l}\text { Rata-rata } \\
\text { indikator }\end{array}$ & $\begin{array}{c}\text { Rata- } \\
\text { rata } \\
\text { varia } \\
\text { bel }\end{array}$ & Ket \\
\hline 1. & $\begin{array}{c}\text { Kualitas } \\
\text { Produk }\end{array}$ & $\begin{array}{l}\text { X1.1 Penampilan produk Xi Bo Bab } \\
\text { Jimbaran } \\
\text { X1.2 Porsi produk Xi Bo Ba } \\
\text { Jimbaran }\end{array}$ & $\begin{array}{l}4.50 \\
4.52\end{array}$ & 4.51 & Sangat baik \\
\hline 2. & Harga & $\begin{array}{l}\text { X2.1 Harga produk Xi Bo Ba } \\
\text { Jimbaran terjangkau untuk konsumen } \\
\text { X2.2 Harga produk Xi Bo Ba } \\
\text { Jimbaran sesuai dengan kualitas } \\
\text { barang }\end{array}$ & 4.18 & 4.20 & Baik \\
\hline \multirow[t]{2}{*}{3.} & Promosi & $\begin{array}{l}\text { X3.1 Xi Bo Ba Jimbaran } \\
\text { memberikan promosi melalui media } \\
\text { social (Instagram, go food, grab, } \\
\text { facebook) }\end{array}$ & 4.49 & 4.49 & Sangat baik \\
\hline & & Rata-rata & & 4.40 & Sangat baik \\
\hline
\end{tabular}

Berdasarkan hasil penilaian konsumen Xi Bo Ba Jimbaran terhadap minat beli konsumen seperti pada tabel 2, selama periode penelitian yaitu bulan Juli 2020, didapatkan hasil nilai rata-rata 4,40 dengan kategori sangat baik. Variable tertinggi pada variabel kualitas produk dan terendah pada variable harga. Demografi responden terbanyak pada perempuan (65\%), umur pada 17-25 tahun (45\%), sebagai siswa/mahasiswa (45\%). Berikut penjelasan pada masing-masing variabel minat beli:

\subsection{Variabel Kualitas Produk (X1)}

Kualitas Produk memiliki 2 indikator yaitu (X1.1) Penampilan produk Xi Bo Ba Jimbaran dan (X1.2) Porsi produk Xi Bo Ba Jimbaran. Berikut ini adalah Tabel 3 mengenai tabel hasil penilaian kepada konsumen Xi Bo Ba terhadap variabel kualitas produk. 
Tabel 3: Tabel Hasil Penilaian Konsumen Terhadap Variabel Kualitas Produk [Sumber: Data diolah (2020)]

\begin{tabular}{lllcl}
\hline No & Variabel & Indikator & Nilai & Ket \\
\hline 1. & $\begin{array}{l}\text { Kualitas Produk } \\
(\text { X1) }\end{array}$ & $\begin{array}{l}\text { X1.1 Penampilan produk Xi } \\
\text { Bo Ba Jimbaran } \\
\text { X1.2 Porsi produk Xi Bo Ba } \\
\text { Jimbaran }\end{array}$ & 4.50 & Sangat Baik \\
\hline Rata-rata & & 4.52 & Sangat Baik \\
\hline
\end{tabular}

Berdasarkan Tabel 3 diatas variabel kualitas produk memiliki rata-rata 4,51 dengan interpretasi sangat baik. Variabel ini didukung oleh dua indikator yaitu (X1.1) penampilan produk Xi Bo Ba Jimbaran yang mendapatkan nilai 4,50 dengan interpretasi sangat baik dan indikator (X1.2) porsi produk Xi Bo Ba Jimbaran mendapatkan nilai 4,52 dengan interpretasi sangat baik. Hal ini menunjukkan bahwa konsumen sangat puas dengan variabel penampilan dan porsi produk yang diberikan oleh perusahaan Xi Bo Ba Jimbaran.

Hasil wawancara langsung dengan responden, disampaikan bahwa penampilan produk Xi Bo Ba sangat menarik. Pada cup plastik yang digunakan untuk presentasi produk, diberikan hiasan caramel dari brown sugar pada pinggir cup sehingga produk sangat menarik. Sedangkan porsi produk Xi Bo Ba juga disampaikan sangat baik artinya konsumen puas dengan porsi yang sudah diberikan. Produk minuman yang digemari adalah Green Tea dan Caramel dengan toping Bo Ba.

\subsection{Variabel Harga (X2)}

Harga memiliki 2 indikator yaitu (X2.1) Harga produk Xi Bo Ba Jimbaran terjangkau untuk konsumen dan (X2.2) Harga produk Xi Bo Ba Jimbaran sesuai dengan kualitas barang. Berikut ini adalah Tabel 4 mengenai tabel hasil penilaian kepada konsumen Xi Bo Ba terhadap Variabel Harga.

Tabel 4: Tabel Hasil Penilaian Konsumen Terhadap Variabel Harga [Sumber: Pertanyaan Yang Disesuaikan Dengan Indikator Minat Beli]

\begin{tabular}{|c|c|c|c|c|}
\hline No & Variabel & Indikator & Nilai & Ket \\
\hline \multirow{3}{*}{2.} & \multirow{3}{*}{ Harga (X2) } & $\begin{array}{l}\text { X2.1 Harga produk Xi Bo Ba } \\
\text { Jimbaran terjangkau untuk } \\
\text { konsumen }\end{array}$ & 4.18 & Baik \\
\hline & & $\begin{array}{l}\text { X2.2 Harga produk Xi Bo Ba } \\
\text { Jimbaran sesuai dengan } \\
\text { kualitas barang }\end{array}$ & 4.22 & $\begin{array}{c}\text { Sangat } \\
\text { Baik }\end{array}$ \\
\hline & & Rata-rata & 4.20 & Baik \\
\hline
\end{tabular}

Berdasarkan Tabel 4 diatas variabel harga mendapatkan rata-rata nilai 4,36 dengan interpretasi sangat baik. Variabel ini didukung oleh 2 indikator yaitu (X2.1) Harga produk $\mathrm{Xi}$ Bo ba Jimbaran terjangkau untuk konsumen mendapatkan nilai 4,27 dengan interpretasi sangat baik dan indikator (X2.2) Harga produk Xi Bo Ba Jimbaran sesuai dengan kualitas barang mendapatkan nilai 4.20 dengan interpretasi baik.

Hasil wawancara dengan para pelanggan pada outlet Xi Bo Ba Jimbaran harga produk Xi Bo Ba disampaikan baik. Harga perporsi produk Xi Bo Ba $475 \mathrm{ml}$ dibandrol dengan harga rata-rata Rp17.000 hingga Rp26.000, dimana harga semestinya sudah sangat terjangkau bila dilihat dari value yang diberikan. Tetapi karena adanya pandemi COVID 19 harga tersebut dirasakan mahal oleh pelanggan. Sedangkan bila dilihat dari penilaian value produk Xi Bo Ba dengan harga sudah sangat baik. Hal ini bila dikaitkan dengan demografi responden tertinggi pada umur 17-25 tahun dengan status sebagai 
siswa dan mahasiswa tentunya ini adalah generasi milenial dan masih diusia belum produktif.

\subsection{Variabel Promosi (X3)}

Promosi memiliki 1 indikator yaitu (X3.1) Xi Bo Ba memberikan promosi melalui media social (Instagram, go food, grab, facebook) Berikut ini adalah Tabel 5 mengenai tabel hasil penilaian kepada konsumen Xi Bo Ba terhadap Variabel Promosi.

Tabel 5: Tabel Hasil Penilaian Konsumen Terhadap Variabel Promosi [Sumber: Pertanyaan Yang Disesuaikan Dengan Indikator Minat Beli]

\begin{tabular}{|c|c|c|c|c|}
\hline No & Variable & Indikator & Nilai & Ket \\
\hline 3. & $\begin{array}{l}\text { Promosi } \\
\text { (X3) }\end{array}$ & $\begin{array}{l}\text { X3.1 Xi Boba Jimbaran memberikan } \\
\text { promosi melalui media social } \\
\text { (Instagram, go food, grab, facebook) }\end{array}$ & 4.49 & Sangat Baik \\
\hline & & Rata-rata & 4.49 & Sangat Baik \\
\hline
\end{tabular}

Berdasarkan Tabel 5 diatas dari variabel promosi mendapatkan rata-rata nilai 4,49 dengan interpretasi sangat baik. Variabel ini didukung oleh indikator (X3.1) Xi Bo Ba Jimbaran memberikan promosi melalui media social (Instagram, go food, grab, facebook) mendapatkan nilai 4,49 dengan interpretasi sangat baik. Hasil wawancara dengan para pelanggan di outlet Xi Bo Ba Jimbaran bahwa Xi Bo Ba ini termasuk selalu update dalam media sosial, dan Xi Bo Ba juga rutin memberikan promo buy 1 get 1 free (beli satu dapat gratis satu). Untuk mengetahui info update mengenai promo yang diberikan bisa melalui akun Instagram Xi Bo Ba yang dimana selalu memberikan informasi dan batas waktu oleh Xi Bo Ba mengenai promosi yang diberikan. Bila dilihat dari demografi responden yang lebih dominan milenial, mereka sangat menyukai promosi secara digital, dan word of mouth serta belanja secara online sehingga perlu dicermati oleh pihak management untuk mendapat perhatian ke depannya.

Dilihat dari analisa data diatas mengenai minat beli konsumen di Xi Bo Ba Jimbaran dapat disimpulkan bahwa minat beli konsumen dalam rentang sangat baik dengan nilai rata-rata 4.40. Minat beli dari segi kualitas produk, harga, promosi dapat memberikan minat beli yang sangat baik kepada konsumen. Dari 60 orang responden terdapat $12 \%$ yang memberikan penilaian kurang dan cukup pada penilaian harga khususnya harga yang terjangkau karena saat ini adanya pandemic COVID 19 yang menyebabkan daya beli masyarakat rendah. Hasil wawancara dengan management Xi Bo Ba Jimbaran bahwa memang disadari kondisi daya beli masyarakat semakin menurun tetapi minat beli masyarakat terhadap minuman kreasi ini masih sangat baik, terutama melalui pembelian online/ delivery. Terbukti dengan tetap meningkatnya penjualan perbulannya. Tetapi hal ini tentunya diperlukan banyak inovasi dan strategi untuk selalu dapat meningkatkan minat beli masyarakat terhadap produk Xi Bo Ba ini khususnya milenials ke depannya.

\section{KESIMPULAN}

Berdasarkan pembahasan yang telah diuraikan dapat disimpulkan bahwa, secara keseluruhan penilaian konsumen terhadap produk minuman Xi Bo Ba mendapatkan nilai 4,40 dengan interpretasi sangat baik. Dilihat dari hasil rekapitulasi kuesioner dan indikator tersebut sudah mendapatkan interpretasi yang sangat baik melalui 3 variabel yaitu: (1) Variabel kualitas produk dengan 2 indikatornya mendapatkan nilai 4.51 dengan interpretasi sangat baik. (2) Variabel harga dengan 2 indikatornya mendapatkan nilai 4.20 dengan interpretasi baik. (3) Variabel promosi dengan 1 indikator mendapatkan nilai 4.49 dengan interpretasi sangat baik. Sehingga variabel tertinggi ada pada kualitas produk dan terendah pada variabel harga

Saran yang dapat diberikan yaitu: (1) variabel kualitas produk untuk tetap menjaga konsistensi, meningkatkan daya produk, dan memberikan inovasi terbaru sehingga para 
konsumen tidak bosan dengan varian itu saja dan para konsumen mendapatkan beragam pilihan rasa. (2) Untuk variabel harga, harga tidak bisa dirubah namun bisa digantikan dengan kualitas produk yang lebih premium. Atau memberikan paket potongan harga pada event tertentu. (3) Untuk variabel promosi, diharapkan untuk selalu aktif dalam sosial media dan memberikan informasi-informasi serta memberikan promo pada akhir bulan dan event tertentu.

\section{DAFTAR PUSTAKA}

Andri Wicaksono, dkk. (2015). Teori Pembelajaran Bahasa (Suatu Catatan Singkat). Yogyakarta: Garudawacha.

Anik. (2010). Definisi Coffee shop. www.wiktionary.com

Dama, D. (2016), Analisa Faktor-Faktor yang Mempengaruhi Minat Beli Konsumen Dalam Memilih Leptop Acer Di Toko Lestari Komputer Manado, Jurnal Berkala Ilmiah Efisiensi, $16(1), 505$.

Dewi, A. C. (2013). Studi Deskriptif Mengenai Tingkat Kepuasan Konsumen Terhadap Tingkat Kualitas Pelayanan Travel " $X$ " Bandung. Skripsi. Bandung : Fakultas Psikologi Universitas Kristen Maranatha.

Hair. (2010) Multivariate Data Analyisis Seventh Edition. Pearson Prentice Hall.

Hariani. (2013). Analisis pengaruh bauran pemasaran terhadap minat beli konsumen menggunakan gas LPG.

Hendarsono, G \& Sugiono, S. (2013). “Analisa Pengaruh Experiential Marketing Terhadap Minat Beli Ulang Konsumen Cafe Buntos 99 Sidoarjo". Jurnal Manajemen Pemasaran Vol. 1 (2). 1-8.

Kotler \& Keller. (2012). Manajemen Pemasaran. Edisi 12. Jakarta: Erlangga.

Kotler, P \& Armstrong. (2010). Principles of Marketing, thirteen edition. New Jersey: Prentice-Hall, Inc.

Kotler, P. dan Kelvin, L. K. (diterjemahkan oleh Bob Sabrana). (2009). Manajemen Pemasaran. Edisi 13. Jilid 1, Jakarta: Erlangga

Kotler, P. (2010). Manajemen Pemasaran. Jakarta : Erlangga.

Lucas, D. B. \& Britt, S. H. (2012). Measuring Advertising Effectiveness. McGrawHill, New York.

Martono, M. \& Iriani. (2014). “Analisis Pengaruh Kualitas Produk, Harga dan Promosi Terhadap Minat Beli Konsumen Produk Batik Sendang Duwur Lamongan". Jurnal Ilmu Manajemen. 2 (2). 687-699.

Nurhayati \& Wahyu, W. M. (2012). Analisis Faktor-Faktor Yang Memprngaruhi Minat Beli Ulang Masyarakat Terhadap Produk Handphone. Value Added: 8 (2). Universitas Muhammadiyah Semarang.

Rai, G. B. \& Mahadewi, E.N.M. (2012). Metodelogi Penelitian Pariwisata. Denpasar : CV Andi Offset.

Satria, A. A. (2017). Pengaruh Harga, Promosi, dan Kualitas Produk Terhadap Minat Beli Konsumen pada Perusahaan A-36. PERFORMA: Jurnal Manajemen dan Start-Up Bisnis. 2 (1)

Setiadi, A, \& Nugroho. (2011). Perilaku Konsumen. Edisi Revisi. Kencana Prenada Media. Jakarta.

Handayani, S. (2012). Aspek Hukum Perlindungan Konsumen dalam Pelayanan Air Bersih pada PDAM Tirtasari Binjai. Jurnal Non Eksakta. 4 (1). 2.

Sugiyono. (2017). Metode Penelitian Kuantitatif, Kualitatif, dan R\&D. Bandung : Alfabeta, $\mathrm{CV}$

Sugiyono. (2013). Metode Penelitian Pendidikan Pendekatan Kuantitatif, Kualitatif, dan $R \& D$. Bandung: Alfabeta. 
Suradi, M \& Yunelly, A. (2012). Faktor-Faktor Yang Mempengaruhi Minat Beli Konsumen Terhadap Produk Tepung Sagu (Studi Kasus Pada Masyarakat Desa Selat Akar Merbau).Jurnal Administrasi Niaga.

Gunawan, T. (2017). Pengaruh Kualitas Produk, Harga, Promosi, dan Citra Merek Terhadap Keputusan Pembelian. Jurnal Ilmu dan Riset Manajemen. 6 (4). 1-17.

Wiantara, I. G. (2016). Bartending \& Mixology. Yogyakarta: CV. ANDI OFFSET.http://balittri.litbang.pertanian.go.id/index.php/berita/info-teknologi/159mengenal-4-macam-jenis-teh diakses pada 25 Juli 2020. 